\title{
PEMBELAJARAN BERBASIS ALAM UNTUK ANAK USIA DINI DI TK ALAM AL AZHAR KUTAI KARTANEGARA
}

\author{
Oleh \\ Sunanik \\ Dosen, IAIN Samarinda, Indonesia \\ sunaniknik@gmail.com
}

\begin{abstract}
Abstrak
Pembelajaran di dalam kelas dengan meja dan kursi belajar menjadi salah satu model pembelajaran konvensional yang umum diterapkan di lembaga TK.Padahal, sesungguhnya proses belajar dapat dilakukan di mana saja termasuk di luar ruangan atau alam bebas. Proses belajar seperti ini menghambat anak untuk mengeksplor kemampuannya secara maksimal. TK Alam merupakan sebuah layanan pendidikan bagi anak yang fokus pada kegiatan outdoor dan pembelajaran melalui interaksi langsung dengan alam. Konsep ini merupakan sebuah inovasi dibidang Pendidikan Anak Usia Dini. Belum banyak penelitian formal yang tersedia tentang pelaksanaan pembelajaran Alam dan belum ada acuan kurikulum yang mengatur pembelajaran di TK alam. Penelitian ini bertujuan untuk mendeskripsikan pembelajaran berbasis alam di TK Alam. Penelitian ini dilakukan menggunakan metode penelitian deskriptif kualitatif pada TK alam yang terdapat di KutaiKartanegara yaitu TK Alam Al Azhar. Alat pengumpul data yang digunakan adalah observasi aktivitas pembelajaran, wawancara dan studi dokumentasi. Dalam penelitian ini, perencanaan pembelajaran di TK Alam menggunakan terdiri dari menetapkan tahap perkembangan Anak Didik, menetapkan indikator, menyusun konsep materi pembelajaran, menentukan tema, menyusun rencana kegiatan pembelajaran berbasis alam, menyiapkan sumber belalar dan alat peraga pembelajaran berbasis alam, pelaksanaan pembelajaran dilakukan didalam kelas (indoor learning) dan diluar kelas (outdoorlearning). Evaluasi pembelajaran dilakukan dengan pengamatan, catatan anekdot, danfortofolio kemudian dituangkan dalam raport perkembangan dan raport narasi yang berisi detail perkembangan anak selama di TK.
\end{abstract}

Kata Kunci : Pembelajaran konvensional, TK Alam, Pembelajaran Inovatif, Pelaksanaan Pembelajaran

\section{A. Pendahuluan}

Pendidikan adalah bimbingan atau pimpinan secara sadar oleh penduduk terhadap perkembangan jasmani dan rohani anak menuju

Jurnal Ilmiah AL-MADRASAH, Vol. 3, No. 1, Juli-Desember 2018 
Sunanik: Pembelajaran Berbasis Alam untuk Anak Usia Dini di TK Alam Al Azhar Kutai Kartanegara

terbentuknya kepribadian. ${ }^{1}$ Menurut UU Sisdiknas No. 20 Tahun 2003, Pasal 1 ayat (1) dijelaskan bahwa Pendidikan adalah usaha sadar dan terencana untuk mewujudkan suasana belajar dan proses pembelajaran agar anak didik secara aktif mengembangkan potensi dirinya untuk memiliki kekuatan spiritual keagamaan, pengendalian diri, kepribadian, kecerdasan, akhlak mulia, serta keterampilan yang diperlukan dirinya, masyarakat, bangsa dan Negara.

Anak usia dini merupakan masa yang tepat untuk belajar. Pada masa ini, anak mengalami proses pertumbuhan dan perkembangan yang luar biasa. Anak usia dini adalah anak yang berada di masa golden age yang artinya seorang anak memiliki potensi berkembang yang paling baik. Pada usia ini, fisik otak anak berkembang mencapai $90 \% .^{2}$ Pada masa usia dini ini, pendidikan dititik beratkan pada pertumbuhan dan perkembangan fisik (koordinasi motorik halus dan kasar), kecerdasan (daya pikir, daya cipta, kecerdasan emosi, kecerdasan spiritual), sosio emosional (sikap dan perilaku serta beragama), bahasa dan komunikasi serta seni. Stimulasi yang dikembangkan untuk memberikan pondasi dasar yang kuat agar mampu berkembang optimal di masa selanjutnya. ${ }^{3}$

Husin menyatakan bahwa peran negara dalam proses pendidikan secara umum sangat mempunyai keterikatan antara keduanya. Kebijakan yang dikeluarkan oleh negara terkait tata kelola pendidikan, sumber daya manusia, kurikulum bahkan sampai prosesnya pun tidak lepas dari apa yang sudah

${ }^{1}$ Ahmad D. Marimba, Pengantar Filsafat Pendidikan Islam (Bandung: AlBayan, 1996), h. 19.

${ }^{2}$ Fadillah, M., Desain pembelajaran PAUD: Panduan untuk pendidikan mahasiswa, dan pengelola pendidikan anak usia dini. (Yogyakarta: Ar-Ruzz Media, 2012), h. 62.

${ }^{3}$ Saleh, S., \& Sugito, S., Implementasi metode bermain peran untuk meningkatkan kecerdasan interpersonal anak usia 5-6 tahun di TK Barunawati. Jurnal Pendidikan dan Pemberdayaan Masyarakat, 2(1), 85-93. Retrieved from http://journal.uny.ac.id/index.php/jppm/article/view/4845. 2015, h. 1.

Jurnal Ilmiah AL-MADRASAH, Vol. 3, No. 1, Juli-Desember 2018 
Sunanik: Pembelajaran Berbasis Alam untuk Anak Usia Dini di TK Alam Al Azhar Kutai Kartanegara

dirancang oleh para elite pemerintahan di sebuah negara. ${ }^{4}$ Berdasarkan pandangan seperti itulah sepertinya yang mendorong pemerintah menggalakkan program Pendidikan Anak Usia Dini (PAUD). UU nomor 20 tahun 2003 tentang Sistem Pendidikan Nasional pasal 1 ayat 14 menyebutkan bahwa PAUD adalah suatu upaya pembinaan yang ditujukan pada anak sejak lahir sampai usia 6 tahun. UU tersebut menunjukkan pemerintah Indonesia serius dalam menyelenggarakan PAUD. Pelaksanaan program PAUD di Indonesia diawasi oleh Dirjen PAUDNI. Data jumlah PAUD Nasional sampai tahun 2015 ada 188.650 lembaga PAUD. Jumlah tersebut terdiri atas TK sejumlah 102.144 lembaga, KB sejumlah 65.054 lembaga, TPA sejumlah 2.472 lembaga dan SPS 18.825 lembaga. Penyelenggaran lembaga PAUD dikelola oleh pemerintah, swasta, pemerintah desa, maupun perorangan. ${ }^{5}$

Penyelenggaraan PAUD yang banyak mengalami hambatan adalah masih terbatasnya penguasaan ilmu pendidikan para pendidik, masih terbatasnya dana untuk pembelian alat permainan edukatif (APE), dan masih terbatasnya evaluasi program PAUD. Penyelenggaraan pendidikan di PAUD tersebut disebabkan oleh pendidik belum menguasai pendidikan untuk anak usia dini. Penguasaan pendidik PAUD terhadap anak sangat rendah. Banyak pendidik yang sudah terpola dengan pembelajaran konvensional karena sering melihat pembelajaran pendidikan dasar yang berkembang lebih dahulu di masyarakat. Pendidikan di dalam kelas dengan meja dan kursi belajar menjadi salah satu model pembelajaran yang umum diterapkan di kelompok bermain.

Padahal, sesungguhnya proses belajar dapat dilakukan di mana saja termasuk di luar ruangan atau alam bebas. Proses belajar seperti ini menghambat anak untuk mengeksplor kemampuannya secara maksimal.

${ }^{4}$ Husin Husin, "PENDIDIKAN AGAMA ISLAM DI AMERIKA SERIKAT (Lembaga Pendidikan Islam)," Al-Madrasah: Jurnal Ilmiah Pendidikan Madrasah Ibtidaiyah 2, no. 2 (2018).h. 1.

${ }^{5}$ PERMENDIKBUD 137, Standar Nasional Pendidikan Anak Usia Dini. (Jakarta:Permedikbud. 2014), h. 17.

Jurnal Ilmiah AL-MADRASAH, Vol. 3, No. 1, Juli-Desember 2018 
Sunanik: Pembelajaran Berbasis Alam untuk Anak Usia Dini di TK Alam Al Azhar Kutai Kartanegara

Berdasarkan permasalahan tersebut, maka PAUD memerlukan inovasi pembelajaran agar menyenangkan bagi anak. Amalee mengatakan bahwa pendidikan anak usia dini memerlukan sebuah pembelajaran yang menyenangkan sesuai dengan cara belajar anak. Metode belajar mengajar di sekolah konvensional membuat anak usia dini sulit menangkap pelajaran yang disampaikan oleh pendidik. Salah satu alternatif model pembelajaran yang dapat digunakan untuk mengembalikan hakikat belajar anak adalah Model Pembelajaran Berbasis Alam (PBA). Lingkungan sekitar dapat dijadikan sebagai alternatif untuk kegiatan belajar mengajar. Model ini diharapkan dapat menjalin keselarasan antara materi pembelajaran dengan lingkungan alam sekitar. Alam memiliki banyak pengetahuan. Alam adalah pendidik sesungguhnya. Alam merupakan salah satu media pembelajaran serta dapat digunakan sebagai tempat untuk melakukan proses belajar mengajar. Oleh karena itu wajar jika banyak PAUD mengambil alam sebagai sumber inspirasi belajar. Anak dikenalkan alam sejak dini, diajak turun ke sawah, menangkap ikan, hingga berjalan jalan ke hutan. Mereka diajari keterampilan hidup di alam.

Filosofis pendidikan yang berbasis lingkungan alam sebenarnya telah digagas pertama kali oleh Jan Lightghart pada tahun 1859. Tokoh ini menyajikan suatu bentuk model pendidikan yang dikenal dengan 'pengajaran barang sesungguhnya'. Konsep ini menjadi salah satu akar munculnya konsep pendidikan yang berbasis pada alam atau back to nature school. Ide dasarnya adalah pendidikan pada anak dilakukan dengan mengajak anak dalam suasana sesungguhnya melalui belajar pada lingkungan alam sekitar yang nyata. Bentuk pengajaran ini dilakukan sebagai upaya menentang bentuk pengajaran yang cenderung intelektualisme dan verbalistik. Menurut Jan Lightghart, Sumber utama bentuk pengajaran ini adalah lingkungan di sekitar anak. Melalui bentuk pengajaran ini akan tumbuh keaktifan anak dalam mengamati, menyelidiki serta mempelajari lingkungan. Kondisi lingkungan yang sesungguhnya juga akan menarik perhatian spontan anak sehingga anak memiliki pemahaman dan kekayaan pengetahuan yang bersumber dari lingkungannya sendiri. Bahan- 
Sunanik: Pembelajaran Berbasis Alam untuk Anak Usia Dini di TK Alam Al Azhar Kutai Kartanegara

bahan pengajaran yang ada pada lingkungan sekitar anak akan mudah diingat, dilihat dan dipraktikan sehingga kegiatan pengajaran menjadi berfungsi secara praktis.

Inti pengajaran sesungguhnya adalah mengajak anak pada kondisi lingkungan sesungguhnya. Semua bahan yang ada di lingkungan sekitar anak dapat dipakai sebagai pusat minat atau pusat perhatian anak. Bahan pengajaran dari lingkungan oleh Jan Lighthart dikelompokan dalam tiga kategori, yaitu: Lingkungan alam (sebagai bahan mentah), lingkungan produsen atau lingkungan pengrajin (pengolah dan penghasil bahan mentah menjadi bahan jadi) serta lingkungan masyarakat pengguna bahan jadi (konsumen). Bahan ini dapat terdiri dari tanaman, tanah, batu-batuan, kebun, sungai dan ladang, pengarajin kayu, rotan dan pasar atau toko sebagai pusat jual beli bahan-bahan jadi tersebut. Berdasarkan pusat minat anak (tema) ini maka langkah pengajaran dilaksanakan.

Landasan filosofis kedua dapat ditelaah dari filsafat pendidikan naturalisme romantik yang dikemukakan Rousseau. Filosof ini berusaha mengembangkan konsep pendidikan yang dilakukan secara naturalistik atau alami. Ia mengemukakan filosofisnya bahwa : (1) pendidikan harus mengembangkan kemampuan-kemampuan alami atau bakat/pembawaan anak dan (2) pendidikan yang berlangsung dalam alam. Sesuai dengan pandangan di atas, maka pendekatan untuk mendidik anak bukanlah dengan mengajar anak secara formal atau melalui pengajaran langsung, akan tetapi dengan memberi kesempatan kepada mereka belajar melalui proses eksplorasi dan discovery.

Sekolah alam saat ini di pandang sangat cocok untuk di gunakan pada pendidikan anak usia dini di daerah perumahan yang padat akan penduduk. Karena anak-anak pada usia dini yang bertempat tinggal di perumahan tidak mempunyai area untuk bermain dan mengeksplorasikan dirinya, anak anak yang bertempat tinggal di perumahan biasanya mempunyai kesulitan bersosial. Maka sekolah alam di anggap cocok untuk mengatasi hal tersebut.

Jurnal Ilmiah AL-MADRASAH, Vol. 3, No. 1, Juli-Desember 2018 
Sunanik: Pembelajaran Berbasis Alam untuk Anak Usia Dini di TK Alam Al Azhar Kutai Kartanegara

Meskipun mulai banyak bermunculan PAUD di Kalimantan Timur, terdapat beberapa PAUD yang melupakan hakikat pendidikan anak yang sebenarnya. PAUD tersebut memberikan pengajaran yang melupakan hakikat pembelajaran anak dimana anak seharusnya belajar melalui bermain dan pembelajaran terjadi dengan menyenangkan, yang terjadi adalah pembelajaran belum sesuai dengan yang diharapkan Anak dituntut untuk segera bisa membaca, menulis dan berhitung sebelum sampai pada tahapan perkembangannya. Tidak sedikit anak merasakan kebosanan di sekolah karena justru tak bisa bermain di PAUD. PAUD dengan model pembelajaran tersebut melupakan prinsip belajar sambil bermain serta pembelajaran bagi anak yang seharusnya sesuai dengan bakat dan minatnya tanpa paksaan. Berubahnya orientasi PAUD yang mengajarkan membaca, menulis dan berhitung bisa jadi dikarenakan tuntutan orang tua dan juga Sekolah Dasar yang banyak mengadakan tes baca sebelum masuk SD sehingga banyak PAUD melupakan prinsip pembelajaran anak. Pendidikan berjalan sangat mekanis dan menganut prinsip profit oriented. Sekolah diorganisasikan seperti target utamanya adalah efesiensi. Akibatnya anak-anak hanya dididik untuk menjadi instrumen untuk meraih efesiensi.

Melihat realitas pendidikan tersebut, orang tua yang mulai mengerti tentang berbagai teori perkembangan anak berkat bantuan teknologi yang makin canggih (internet, televisi, majalah dan seminar) mulai mencari alternatif pendidikan bagi anak. Salah satu alternatif pendidikan anak usia dini yang dipilih orang tua adalah Sekolah Alam atau PAUD dengan model pembelajaran Alam. PAUD Alam adalah PAUD dengan proses inspirasi yang menawarkan anak-anak kesempatan untuk berprestasi dan mengembangkan kepercayaan diri melalui pembelajaran langsung di lingkungan alam terbuka. Konsep PAUD dengan pembelajaran Alam di Indonesia merupakan inovasi baru dibidang pendidikan. Perkembangannya dimulai dengan berdirinya Sekolah Alam yang digagas oleh Lendo Novo pada tahun 1993 dan terealisasi melalui Sekolah Alam Ciganjur pada tahun 1998. Di Negara lain konsep ini lebih dulu dikenal 
Sunanik: Pembelajaran Berbasis Alam untuk Anak Usia Dini di TK Alam Al Azhar Kutai Kartanegara

dengan nama forest kindergarten atau nature kindergarten. PAUD Alam merupakan konsep pendidikan berbasis alam semesta.

Para penggagasnya meyakini bahwa hakikat tujuan pendidikan adalah untuk membantu anak didik tumbuh menjadi manusia yang berkarakter. Menjadi manusia yang tidak saja mampu mencintai dan memelihara alam lingkungannya tetapi juga memiliki kemampuan dasar yakni kemampuan membangun jiwa keingintahuan, melakukan observasi, membuat hipotesis serta berpikir ilmiah.

TK Alam Al Azhar Kutai Kartanegaraadalah salah satu PAUD yang menerapkan pembelajaran berbasis alam. Sebagian orang tua memilih sekolah alam adalah satu kebutuhan untuk mengubah paradigma pendidikan masa depan anak-anak mereka. TK Alam Al Azhar Kutai Kartanegara ini menggunakan kurikulum yang ditetapkan oleh Dinas Pendidikan. TK Alam Al Azhar Kutai Kartanegara ini memadukan antara kurikulum khas sekolah alam dengan Dinas Pendidikan. TK Alam Al Azhar Kutai Kartanegaratidak mengandalkan gedung mewah, bahkan hanya terbuat dari kayu ulin tanpa dinding yang tertutup. Anak Didik pun berseragam bebas, walaupun ada disediakan satu seragam khusus dari sekolah yaitu baju batik. Baju itu digunakan saat ada kunjungan ke suatu tempat atau saat menghadiri event-event tertentu. Tapi semua itu, bukan hal yang utama bagi Anak Didik.

Pelajaran yang diberikan juga bertahap, terarah dan ada pencapaian. Sekolah alam juga belajar nilai-nilai agama dan moral, sosial emosional, bahasa, sains, kognitif, motorik, dan seni. Belajar juga selalu dilakukan sambil bermain. Misal, berhitung sambil bermain, melempar bola, mewarnai, serta mengenal berbagai macam bentuk. Setiap minggu selalu ada outbond, mulai dari outbond ringan hanya sebatas bermain pasir, bermain di kebun, dan fly fox. Rekreasi seperti kemah, panjat tebing dan memancing. Kemudian, setelah melakukan outbond, diakhiri dengan education game selama 15-30 menit.

Sekolah alam, guru mengikuti gaya belajar anak. Karena setiap anak punya karakter yang berbeda, ada yang senang melihat dan mendengar, ada pula 
Sunanik: Pembelajaran Berbasis Alam untuk Anak Usia Dini di TK Alam Al Azhar Kutai Kartanegara

yang suka lari-lari dengan temannya. Sekolah alam ingin mencetak karakter dan menguji nyali mereka seberapa berani dan mandiri. Dari berbagai fenomena yang menarik tersebut maka peneliti memiliki keinginan untuk melakukan penelitian lebih lanjut di TK Alam Al Azhar Kutai Kartanegaradengan mengangkat Tema"Pembelajaran Berbasis Alam untuk Anak Usia Dini di TK Alam Al Azhar Kutai Kartanegara"

\section{B. Metode Penelitian}

Penelitian ini mengguanakan penelitian kualitatif. Pendekatan penelitian ini adalah deskriptif analisis dari Pembelajaran Berbasis Alam Untuk Anak Usia Dini Di TK Alam Al Azhar Kutai Kartanegara. Metode Pengumpulan Data dalam penelitian ini adalah dengan teknik observasi, wawancara dan dokumentasi. Analisis data dalam penelitian ini melalui dua tahap pertama selama pengumpulan data dan kedua setelah data terkumpul, keseluruhan proses pengumpulan data dan penganalisisan data penelitian kualitatif berdasarkan model analisis interaktif, sebagaimana yang dikembangkan oleh Milles Huberman, yaitu: reduksi data (data reduction), sajian data (data display), dan penarikan kesimpulan ((data conclusion). ${ }^{6}$

\section{Teori Pembelajaran Berbasis Alam}

Darmawan dan Permasih menyebutkan bahwa pembelajaran merupakan proses membelajarkan siswa yang belajar. $^{7}$ Pembelajaran (Instruction) merupakan akumulasi dari konsep mengajar (teaching) dan konsep belajar (learning). Penekanannya terletak pada perpaduan antara keduanya, yakni kepada perubahan aktivitas dan perubahan positif subjek didik. Pembelajaran berbasis alam adalah proses belajar yang mengintegrasikan antara

${ }^{6}$ Milles Huberman, Michael and Mattew. B, Analisis Data Kualitatif, (terj), (Jakarta: UI Press, 1984), h. 32.

${ }^{7}$ Darmawan dan Permasih, Konsep Dasar Pembelajaran dalam Tim Pengembang MKDP Kurikulum dan Pembelajaran, (Jakarta: PT Rajagrafindo Persada, 2011), h. 128.

Jurnal Ilmiah AL-MADRASAH, Vol. 3, No. 1, Juli-Desember 2018 
Sunanik: Pembelajaran Berbasis Alam untuk Anak Usia Dini di TK Alam Al Azhar Kutai Kartanegara

materi ajar dan lingkungan alam sekitar. Sehingga akan mengembangkan pengetahuan siswa. Siswa bersama guru bersama-sama mengkonstruksi pengetahuan yang baru yang terus berkembang. Implementasi pembelajaran berbasis alam tidak harus di luar ruangan namun demikian apa yang ada di luar ruang dapat dialihkan di dalam ruang kelas dengan berbagai macam model pendekatan pembelajaran. Proses pembelajaran berbasis alam adalah proses belajar di mana subjek melakukan sesuatu bukan hanya memikirkan sesuatu.

Ide dasar pembelajaran berbasis alam adalah pendidikan pada anak dilakukan dengan mengajak anak dalam suasana sesungguhnya melalui belajar pada lingkungan alam sekitar yang nyata. Bentuk pengajaran ini dilakukan sebagai upaya menentang bentuk pengajaran yang cenderung intelektualisme dan verbalistik. Menurut Jan Lightghart, Sumber utama bentuk pengajaran ini adalah lingkungan di sekitar anak. Melalui bentuk pengajaran ini akan tumbuh keaktifan anak dalam mengamati, menyelediki serta mempelajari lingkungan. Kondisi lingkungan yang sesungguhnya juga akan menarik perhatian spontan anak sehingga anak memiliki pemahaman dan kekayaan pengetahuan yang bersumber dari lingkungannya sendiri.

Pembelajaran berbasis alam menjadikan pengetahuan dan pengalaman yang diperoleh oleh siswa lebih dekat dan mensyukuri ciptaan Allah, memiliki perilaku $^{8}$ atau sikap mental yang kuat, ia menjadi penyayang tumbuhan, binatang dan juga alam sekitarnya, selain itu siswa juga memiliki sikap yang baik dan ramah terhadap alam. Mereka menjadi terbiasa dan terampil berinteraksi dengan alam sekitar dengan baik, serta mempunyai keterampilan untuk bertahan hidup ketika dalam kondisi sempit.

\section{Deskripsi Hasil Penelitian}

${ }^{8}$ Sebagaimana menurut Agus Setiawan dalam artikel bahwa cakap berperilaku akan mampu berperan aktif dalam membangun kehidupan bersama, baik di lingkungan rumah, sekolah dan bahkan di masyarakat. Lihat Agus Setiawan, Prinsip Pendidikan Karakter dalam Islam (Studi Komparasi Pemikiran al-Ghazali dan Burhanuddin al-Zarnuji), Dinamika Ilmu, 14 (1), 2014, hlm. 7.

Jurnal Ilmiah AL-MADRASAH, Vol. 3, No. 1, Juli-Desember 2018 
Sunanik: Pembelajaran Berbasis Alam untuk Anak Usia Dini di TK Alam Al Azhar Kutai Kartanegara

Pembelajaran pendidikan anak usia dini merupakan kegiatan belajar mengajar yang berpusat pada anak. Pada masa ini anak mengalami beragam peristiwa, maka sistem pembelajarn yang dibangun sangat menentukan kepada anak didik untuk bisa mengalami pertumbuhan dan perkembangan yang maksimal. Dalam proses pembelajaran secara umum di TK Alam Al AzharKutai menggunakan kurikulum 2013 yang disempurnakan dengan Kurikulum Tingkat Satuan Pembelajaran (KTSP). Dengan maksud dari penjabaran yang lebih spesifik pada pelaksanaannya yaitu ditambah kurikulum lokal yang dikaitkan dengan kearifan lokal.

Sebagai sekolah berbasis agama Islam, maka kurikulum yang digunakan dan dikembangkan sedemikian rupa menjadi penting untuk mendesainnya dengan menyandingkan melalui strategi pendekatan pembelajaran terintegrasi. Dalam penyajiannya materi dan desain pembelajarannya berbasis pada lingkungan sekitar seperti berkebun. Lebih jauh lagi penggunaan kurikulum dengan strategi pendekatan contextual teaching and learning (CTL) untuk dapat menanamkan nilai dengan memanfaatkan realitas lingkungan. Antara materi dan situasi menjadi saling terkait sehingga pembelajaran dapat dimaksimalkan secara menyeluruh. Bermain diantaranya merupakan suatu aktivitas yang langsung, spontan di mana seorang anak berinteraksi dengan orang lain, benda-benda disekitarnya, dilakukan dengan senang (gembira) atas inisiatif sendiri, menggunakan daya khayal(imaginatif), menggunakan panca indera, dan seluruh anggota tubuhnya. Anak menemukan nikmatinya dalam belajar. Sedangkan belajar dijadikan satu kegiatan dalam kegiatan pembelajaran bermain anak, dan inilah yang diterapkan dengan menciptakan kesenangan (fun learning) pada pelaksanaannya sehingga pendekatan dalam pembelajaran dengan beragam dilakukan untuk mendukung segala aktifitas.।

Pembelajaran berbasis alam di TK Alam AlAzhar Kutai Kartanegara terdiri dari perencanaan, pelaksanaan dan evaluasi. Perencanaan pembelajaran merupakan tahapan yang penting dalam pelaksanaan pembelajaran. Berikut 
Sunanik: Pembelajaran Berbasis Alam untuk Anak Usia Dini di TK Alam Al Azhar Kutai Kartanegara

akan peneliti paparkan masing-masing perencanaan pembelajaran di TK Alam Al Azhar Kutai Kartanegara yang berkaitan dengan Pembelajaran pembelajaran berbasis alam.

1. Perencanaan Pembelajaran berbasis alam

Perencanaan pembelajaran berbasis alam yang dilakukan di TK Alam Al Azhar Kutai Kartanegara terdiri dari menetapkan tahap perkembangan peserta didik, menetapkan indikator, menyusun konsep materi pembelajaran, menentukan tema, menyusun rencana menyusun rencana kegiatan program semester (PROMES), kegiatan mingguan (RPPM) dan harian (RPPH) berbasis alam kegiatan pembelajaran berbasis alam, menyiapkan sumber belalar dan alat peraga pembelajaran berbasis alam. Berdasarkan hasil wawancara pada tanggal 19 April 2018, diperoleh data tentang perencanaan pembelajaran sebagai berikut:

Tahap awal dalam perencanan pembelajaran berbasis alam dengan menetapkan tahap perkembangan anak didik. Berdasarkan wawancara didapat data sebagai berikut:

Setiap Guru harus memahami karakteristik anak-anak, karena anak usia dini mempunyai karakteristik yang berbeda dengan orang dewasa. Karakteristik tersebut meliputi berbagai hal mulai dari agama dan moral, bahasa, kognitif, sosial emosional, fisik, serta kemampuan lainnya.Untuk itu dalam memberikan materi pembelajaran harus disesuaikan dengan karakteristik masing-masing anak. (CW.1)

Masa anak usia PAUD merupakan masa yang paling penting sepanjang kehidupannya, masa usia dini merupakan masa peka bagi anak sehingga para ahli menyebutnya The Golden Age. Guru harus mampu mengetahui semua perkembangan Anak Didik dimana hal tersebut merupakan tahapan awal dari sebuah perencanaan pembelajaran. Pendidikan anak usia dini merupakan usia persiapan anak untuk menerima pendidikan selanjutnya di sekolah dasar. Sehingga dibutuhkan suatu 
Sunanik: Pembelajaran Berbasis Alam untuk Anak Usia Dini di TK Alam Al Azhar Kutai Kartanegara

pembelajaran yang mampu untuk merangsang perkembangan kompetensi anak usia dini.

Tahap kedua dalam perencanaan pembelajaran berbasis alam di TK Alam Al AzharKutaiKartanegara yaitu dengan menetapkan indikator pembelajaran. Indikator pembelajaran dapat dijabarkan dengan membuat Program Semester (PROSEM), Rencana Program Pembelajaran Mingguan (RPPM) dan Rencana Program Pembelajaran Harian (RPPH). Berdasarkan wawancara didapat data sebagai berikut:

Perencanaan Program Semester dibuat bersama-sama dengan Ustdzah-Ustadzah setiap awal semester. RPPM dibuat setiap minggu sedangkan RPPH dibuat sehari sebelum kegiatan pembelajaran direncanakan dan dilaksanakan oleh Ustadzah yang sama, jadi semua ustadzah mutlak membuatnya, sehingga kegiatan disesuaikan dengan situasi dan kondisi yang ada. (CW.1)

Data hasil wawancara tersebut menggambarkan bahwa perencanaan pembelajaran di TK Alam Al Azhar Kutai Kartanegara disusun sendiri oleh kepala sekolah dan guru, sehingga dalam penyusunannya dapat disesuaikan dengan Visi, Misi, tujuan sekolah dan kondisi yang ada dilapangan. Data wawancara tersebut diperkuat dengan analisis data studi dokumen sebagai berikut:

Perencanaan pembelajaran dimulai dari penyusunan program semester. Pada program semester terdapat aspek perkembangan yang diharapkan dapat dicapai dalam waktu satu semester. Adapun aspekaspek perkembangan sesuai dengan standar Tingkat Pencapaian Perkembangan dari Diknas (CD.1)

Indikator-indikator yang tercantum pada program semester diturunkan di Rancangan Pelaksanaan Pembelajaran Mingguan (RPPM). Setiap Minggu, ada indikator yang harus dicapai pada masing-masing aspek perkembangan. Pada RPPM harus terperinci indikator apa saja yang harus dicapai dalam waktu satu minggu (CD.2).

Dari RPPM diturunkan lagi pada rancangan pelaksanaan pembelajaran harian (RPPH). Pada RPPH terdapat tujuan yang harus dicapai anak melalui tema tertentu, maka indikator-indikator 
Sunanik: Pembelajaran Berbasis Alam untuk Anak Usia Dini di TK Alam Al Azhar Kutai Kartanegara

pembelajaran yang sudah ditentukan untuk hari tersebut harus dicapai (CD. 2)

Berdasarkan hasil analisis studi dokumen diperoleh data bahwa perencanaan pembelajaran yang berkaitan dengan pembelajaran berbasis alam, pada program semester telah tertuang secara rinci indikator-indikator pembelajaran yang hendak dicapai. Selanjutnya, indikator-indikator tersebut diturunkan pada RPPM, dan akanditurunkan lagi pada RPPH untuk mencapai tujuan tema pembelajaran.Tujuan Guru menyusun RPPM dan RPPH yaitu untuk memudahkan guru dalam mempersiapkan bahan dan materi pembelajaran. Dalam menyusun RPPM dan RPPH guru dituntut menguasai strategi pembelajaran dengan cara menguasai materi dengan baik sehingga dapat membuat persiapan pembelajaran. Hal tersebut dapat dimaknai bahwa penyusunan RPPM dan RPPH mutlak dilakukan oleh guru, selain berfungsi untuk perencanaan juga berfungsi untuk memperdalam dan sarana untuk memahami materi pelajaran yang akan diberikan kepada anak didik.

Tahap yang ketiga dari perencanaan adalah guru menetapkan tema pembelajaran yang berbasis alam. Tema merupakan pokok pembelajaran yang akan disampai guru didalam proses pembelajaran. Setiap tema dibahas dalam satu minggu atau dua minggu tergantung dari keluasan cakupan dan kedalaman tema tersebut. Hal tersebut mendukung wawancara dan observasi peneliti dilapangan bahwa tema yang ditetapkan di TK Alam Al Azhar Kutai Kartanegara sesuai dengan lingkungan yang dikenal anak dan di sekitarnya. Paparan tersebut dapat dimaknai bahwa penetapan tema sesuai dengan kebutuhan anak didik dan lingkungannya.

Tahap keempat dalam perencanaan adalah dengan menyusun konsep materi pelajaran barbasis alam. Guru-guru TK Alam Al Azhar Kutai Kartanegara menyusun konsep materi pembelajaran berbasis alam secara bersama dalam musyawarah. Menyusun konsep materi pembelajaran dalam perencanaan pembelajaran merupakan sesuatu yang harus dilakukan oleh 
guru. Karena di dalam materi itulah akan disampai suatu pembelajaran yang bermakna dan amanat atau inti dari suatu pembelajaran.

Materi dibuat berdasarkan tema yang sudah ditentukan. Ketika tema tanaman dan sub temanya sayuran maka guru harus bisa menentukan sayuran apa yang akan dibahas dalam sehari. Misal: menjelaskan sayur kangkung maka agar anak memahami apa itu kangkung, Ustadzah tidak sekedar menjelaskan tentang bagian-bagian kangkung, ciri-ciri, manfaat dan cara menjabutnya, tapi Ustadzah mengajak anak didik langsung ke kebun kangkung. (CW.2)

Berdasarkan hasil observasi ketika ke kebun kangkung, kegiatan yang dilakukan ustazdah dan anak didik yaitu setelah guru mencontohkan cara mencabut kangkung, anak langsung disuruh menjabut sendiri dan disuruh menghitung berapa kangkung yang sudah dicabut. Kemudian menghitung daun yang ada di setiap kangkung. Setelah itu disuruh menceritakan pengalaman masing-masing anak setelah ke kebun kangkung.

Perencanaan kelima yaitu penataan ruang kelas dengan memanfaatkan lingkungan alam berangkat dari idealisme Ibu Yuliani, S.Pd selaku Kepala sekolah dibuat konsep tersebut dengan harapan memberikan keleluasaan pada anak untuk bereksplorasi dan menjadi kewajiban guru dan pihak terkait di dalam sekolah untuk meramu/memodifikasi sarana dan prasarana untuk menjadi lebih menarik bagi anak didik. Perencanaan dalam penataan ruang kelas disusun berdasarkan sentra. Berdasarkan wawancara didapat data sebagai berikut:

Setiap hari dibuka satu sentra, setiap hari senin dibuka sentra persiapan dan metode alif, sentra imtaq dibuka setiap hari karena setiap hari melaksanakan sholat dhuha, hari selasa dibuka sentra balok, kemudian hari rabu dibuka sentra seni, dan hari kamis dibuka sentra sains.(CW.1)

Perencanaan kelas yang memanfaatkan lingkungan alam dilakukan sesuai dengan tema yang akan disampaikan dalam pembelajaran. Misalkan 
Sunanik: Pembelajaran Berbasis Alam untuk Anak Usia Dini di TK Alam Al Azhar Kutai Kartanegara

tema tanaman sub tema sayur kangkung, anak didik diajak untuk ke kebun mencabut kangkung langsung sambil melakukan pengamatan. Pemakaian kelas alam yang dilakukan di sekitar lingkungan sekolah, guru secara bergantian melakukan kegiatan belajar dengan berkoordinasi dengan guru yang lainnya. Bangunan fisik kelas dan tata letak ruang direncanakan dengan harapan dapat memberikan kenyamanan, keleluasaan gerak anak, sirkulasi udara, cahaya yang baik untuk menghindari mata lelah pada anak yang berpengaruh pada daya serap atau berhasil tidaknya kegiatan belajar di kelas. Penataan tempat duduk diatur secara fleksibel dengan memberikan kebebasan anak didik untuk memilih meja masing-masing.

Tahap selanjutnya dalam perencana pembelajaran berbasis alam di TK Alam Al Azhar Kutai Kartanegara adalah menyiapkan bahan dan alat peraga pembelajaran. Alat dan bahan pembelajaran berbasis dapat di luar kelas (outdoor) misalnya sains, berkebun, mancing, bermain bebas, ekspedisi, perosotan, jungkat jungkit, papan titian, pasir, tumbuhan sekitar kolam ikan, sedangkan di dalam kelas misalnya Morning Talk, Al-Qur'an (Mengaji dan tahfizd), Library (Perpustakaan), krayon, unit balok lego, bak air botol tempat air, puzzle, gunting, krayon. Hal tersebut dapat dimaknai bahwa penataan ruang kelas yang baik dan terencana dengan berbagai macam media,alat dan bahan pembelajaran dapat meningkatkan pemahaman anak didik terhadap materi yang diajarkan oleh guru.

2. Pelaksanaan Pembelajaran Pembelajaran berbasis alam

Berdasarkan hasil observasi di lapangan, diperoleh data tentang pelaksanaan pembelajaran sentra di TK Alam Al AzharKutaiKartanegara sebagai berikut.

Pelaksanaan pembelajaran pembelajaran berbasis alam dimulai dengan penjemputan dan penyambutan anak (07.30-08.00) pelaksanaan pijakan lingkungan main oleh guru sebelum anak datang (08.00-08.30), Pijakan sebelum main (08.30-09.30), istirahat 
Sunanik: Pembelajaran Berbasis Alam untuk Anak Usia Dini di TK Alam Al Azhar Kutai Kartanegara

(09.30-10.00), pijakan saat main atau inti (10.00-11.30), pijakan setelah main atau penutup (11.30-12.00) (CD.2)

Data hasil analisis observasi tersebut menunjukan bahwa urutan pembelajaran pada pembelajaran berbasis alam dimulai dari penjemputan dan penyambutan, pelaksanaan pijakan lingkungan, pijakan sebelum main, pijakan saat main, dan pijakan setelah main.

Masih dari hasil observasi, diperoleh data bahwa urutan pelaksanaan pembelajaran pembelajaran berbasis alam di TK Alam Al Azhar Kutai Kartanegara adalah sebagai berikut:

Setiap hari Anak didik diantar jemput oleh pihak yayasan. Kemudian sampai sekolah ustadzah menyambut anak-anak yang sudah tiba di sekolah tepat pukul 08.00, kemudian anak didik dibiasakan menaruh tas, melepas sepatu dan menaruh tas dan sepatu mereka di tempat yang sudah disediakan. Setelah itu secara langsung kepala sekolah yang memimpin waktu itu untuk baris-berbaris diselingi dengan bernyanyi dan pengembangan motorik kasar anak dengan melakukan gerak dan lagu. Kemudian dilanjutkan dengan wudhu, karena kran di tempat wudhu terbatas, untuk itu laki-laki dipersilahkan dulu baru anak perempuan. Setelah itu melaksanakan sholat dhuha berjamaah, pemimpin sholat dhuha setiap hari berganti meski belum hafal semua doanya dengan bimbingan ustdzah-ustdzahnya (08.00-08.30). Saat anak istirahat guru mulai menyiapkan alat main yang akan digunakan untuk pembelajaran, sehingga saat anak memasuki ruang lingkungan bermain telah siap digunakan. Pijakan sebelum main dimulai pukul (08.30-09.30) dan anak mulai melaksanakan kegiatan bermain pukul (10.00-11.30), saat kegiatan bermain diselingi mengaji qiraati dipanggil satu persatu dan pukul 11.30 guru mengajak anak untuk merapikan alat main. Selanjutnya pukul 12.00 setelah alat dan lingkungan main selesai dirapikan, guru mengajak anak untuk duduk melaksanakan kegiatan setelah main atau penutup.

Berdasarkan data studi dokumen, diperoleh data tentang pelaksanaan pijakan lingkungan main pada pembelajaran berbasis alam adalah sebagai berikut:

Tujuan dari pelaksanaan pijakan lingkungan main antara lain untuk membantu dan memperlancar kegiatan main anak terkait alat main, menciptakan suasana lingkungan main yang menyenangkan bagi anak dan agar kegiatan bermain dapat berlangsung dengan teratur

Jurnal Ilmiah AL-MADRASAH, Vol. 3, No. 1, Juli-Desember 2018 
Sunanik: Pembelajaran Berbasis Alam untuk Anak Usia Dini di TK Alam Al Azhar Kutai Kartanegara

dan efektif sesuai tujuan. Manfaat dari pelaksanaan pijakan lingkungan main antara lain kegiatan main anak dapat berjalan dengan lancar, anak dapat bermain dengan lingkungan yang menyenangkan dan anak dapat mengembangkan kemampuan sesuai tujuan kegiatan pembelajaran (CD.10).

Sedangkan prosedur pelaksanaan pijakan lingkungan main yaitu; 1) Pendidik menyiapakan alat main yang akan digunakan anak maksimal 30 menit sebelum anak datang. 2) Memastikan bahwa lingkungan belajar di dalam (indoor) dan di luar (Outdoor) bersih, aman, nyaman dan menyenangkan. 3) penataan alat main harus berdasarkan RPPH yang sudah dibuat. 4) Alat bermain yang ditata harus mewakili 3 jenis main yaitu main sensori, main peran dan main pembangunan untuk memberikan pengalaman bermain yang beragam, 5) Alat main ditata di area yang aman, Jika bermain menggunakan air pastikan bahwa tanah tidak licin, sehingga anak tidak terpeleset, 6) Penataan alat main mendukung perkembangan bahasa, kognitif, sosial-emosional anak, 7) Alat main yang ditata dapat digunakan dengan berbagai cara sehingga menumbuhkan kreativitas anak, 8) Alat main yang disiapkan dipastikan dalam kondisi baik, lengkap setnya, tidak retak. 9) Alat dan bahan main serta buku ditata pada tempat yang mudah dijangkau oleh anak, 10) Disiapkan tempat untuk membereskan mainan sesuai dengan kategorinya.

Pelaksanaan pembelajaran berbasis alam di TK Alam Al Azhar Kutai Kartanegara dilaksanakan di dalam kelas (indoor learning) dan di luar kelas (out door learning). Pembelajaran di luar kelas di buat senyata mungkin dengan melihat, mengamati dan berinteraksi dengan objek secara langsung, sehingga pembelajaran tersebut menjadi bermakna dan dapat memberi pengalaman nyata. Pembelajaran berbasis alam yang dilakukan TK Alam Al Azhar Kutai Kartanegara juga menyimpulkan kualitas pembelajaran di luar kelas memberikan pengalaman yang sangat berharga bagi anak didik. Hal tersebut dapat dimaknai bahwa pembelajaran berbasis 
Sunanik: Pembelajaran Berbasis Alam untuk Anak Usia Dini di TK Alam Al Azhar Kutai Kartanegara

alam yang dilaksanakan di luar kelas dapat meningkatkan pemahaman anak didik terhadap materi yang disampaikan guru.

Berdasarkan observasi dilapangan yang dilakukan oleh peneliti menunjukkan bahwa anak didik yang melakukan pembelajaran di luar kelas sangat antusias dan sangat senang sekali. Pemanfaatan lingkungan sekolah yang rindang dengan berbagai tanaman sebagai tempat belajar juga merupakan suatu metode yang sangat efektif. Pembelajaran berbasis alam dengan memanfaatkan benda-benda nyata di lingkungan sekolah. Anak didik lebih memahami peran planet Mars dalam tatanan tata surya melalui pengamatan dan praktik langsung pada jalur tata surya yang sudah dipersiapkan dengan menggunakan tali rafia. Hal tersebut dapat dimaknai bahwa Anak Didik dapat dengan mudah memahami materi dengan mengamati bendanya secara langsung nyata. Pembelajaran di luar kelas dengan praktik langsung dan melakukan eksperimen langsung dengan suasana alam yang menyenangkan akan meningkatkan kemampuan berfikir positif dan kreatif Anak Didik. Hal ini dapat dimaknai bahwa pembelajaran di alam terbuka akan menjadikan Anak Didik lebih kreatif.

Pembelajaran berbasis alam juga dilaksanakan di dalam kelas, dengan cara semua bahan dan alat yang berhubungan dengan alam di pindah ke dalam kelas misalnya tumbuhan kecil, sayuran, buah-buahan , daun, batu, pasir, tanah, ranting, hewan dan sebagainya yang memungkinkan untuk dibawa masuk kedalam kelas. Kemudian Anak Didik dibuat berkelompok untuk mengamati melihat dan berinteraksi dengan benda secara langsung. Pembelajaran yang dilakukan TK Alam Al Azhar Kutai Kartanegara dengan pembelajaran secara berkelompok di dalam kelas. Contohnya dengan satu materi tentang berbagai macam daun anak didik dapat melakukan pengamatan, kemudian ada yang bertanya, setelah itu anak akan mengumpulkan informasi yang diperoleh, kemudian anak bisa menalar dan mengkomunikasikan apa yang dipelajari. Dengan begitu materi yang dipelajari langsung berkesan dan akan ingat terus. Hal 
Sunanik: Pembelajaran Berbasis Alam untuk Anak Usia Dini di TK Alam Al Azhar Kutai Kartanegara

itu dapat maknai bahwa dengan materi yang sama dapat dilakukan pembelajaran yang bervariasi baik di dalam ruangan maupun menggunakan lingkungan alam sebagai sumber belajar.

3. Evaluasi Pembelajaran Pembelajaran berbasis alam

Pada sub subbab ini, peneliti akan mendeskripsikan 2 kompenen utama dalam evaluasi pembelajaran pembelajaran berbasis alam, yaitu penilaian dan tindak lanjut yang dilakukan oleh TK Alam Al AzharKutaiKartanegara.

Penilaian berdasarkan hasil wawancara, diperoleh data tentang penilaian yang dilakukan dalam proses pembelajaran sebagai berikut:

Ada empat teknik yang dilakukan dalam penilaian, yang pertama adalah observasi, yaitu untuk mengamati sejauh mana perkembangan anak dalam mencapai indikator pengembangan. Yang kedua adalah unjuk kerja, yang ketiga hasil karya, dan yang keempat adalah penugasan (CD.9)

Sedang instrumen yang digunakan dalam penilaian pembelajaran pembelajaran berbasis alam yaitu ada 2, yaitu lembar checklist dan catatan anekdot. Lembar checklist diisi setiap hari untuk menilai sejauh mana anak mencapai indikator perkembangan dalam pelaksanaan pembelajaran, sedang catatan anekdot digunakan untuk menulis perilaku unik yang muncul pada anak saat pelaksanaan pembelajaran (CW.1)

Berdasarakan data studi dokumen dan wawancara tersebut menggambarkan bahwa penilaian pembelajaran sentra pembangunan di TK Alam Al Azhar Kutai Kartanegara menggunakan teknik observasi, unjuk kerja, hasil karya dan penugasan. Sedangkan instrumen penelitian yang digunakan ada dua yaitu lembar checklist dan catatan anekdot. berikut:

Data wawancara tersebut diperkuat oleh data observasi yaitu sebagai

Pada saat pembelajaran guru kelas melakukan penilaian dengan observasi dan mengisi lembar checklist. Guru mengamati anak dari pijakan sebelum main hingga pijakan setelah main (CL.1-11).

Berdasarkan hasil observasi menjabarkan bahwa penilaian yang dilakukan dengan cara observasi, unjuk kerja, hasil karya, dan penugasan. 
Sunanik: Pembelajaran Berbasis Alam untuk Anak Usia Dini di TK Alam Al Azhar Kutai Kartanegara

Keempat teknik tersebut digunakan untuk mengisi lembar checklist maupun catatan anekdot.

Dalam pembelajaran berbasis alam TK Alam Al Azhar Kutai Kartanegara melakukan penilaian pembelajaran. Penilaian adalah serangkaian kegiatan yang dirancang untuk mengukur keefektifan sistem mengajar/belajar sebagai suatu keseluruhan. Penilaian yang dilakukan oleh guru meliputi tiga hal yaitu pengamatan, catatan anekdot, dan fortofolio. Guru merupakan salahsatu pondasi penting dalam semua sistem pendidikan. Hasil penelitian tersebut membahas mengenai evaluasi untuk meningkatkan kualitas guru, guru yang berkualitas dapat melakukan penilaian dengan baik dan benar untuk meningkat prestasi belajar anak didik. Hal tersebut dapat dimaknai bahwa guru yang berkualitas dapat melakukan berbagai macam penilaian dengan pengamat, catatan anekdot dan fortofolio secara menyeluruh dan tuntas. Penilaian dengan pengamatan merupakan suatu bentuk penilaian yang paling sederhana tapi dapat memberikan suatu hasil yang sangat bermakna, penilaian dengan pengamatan dilakukan untuk menilai aspek afektif atau tingkah laku. Penilaian pada aspek afektif dilakukan dengan pengamatan, jurnal guru, penilaian sendiri, dan penilaian dari rekan. Hal tersebut dapat dimaknai bahwa penilaian pengamatan digunakan untuk menilai pada aspek afektif atau tingkah laku anak didik. Berdasarkan pengamatan dan wawancara menunjukkan Penilaian kedua yang dilakukan oleh guru TK Alam Al Azhar Kutai Kartanegara adalah dengan catatan anekdot, dimana dalam catatan anekdot tersebut guru mencatat semua perkembangan anak didik selama pembelajaran berbasis alam.

Catatan anekdot ini berbentuk tabel yang isinya nomor dan jenis kegiatan. Penilaian dengan catatan anekdot yang di lakukan TK Alam Al Azhar Kutai Kartanegara. Penilaian pada aspek afektif dilakukan dengan pengamatan, jurnal (catatan) guru, penilaian sendiri, dan penilaian dari rekan. Maka dapat dimaknai bahwa penilaian dengan catatan anekdot dapat 
Sunanik: Pembelajaran Berbasis Alam untuk Anak Usia Dini di TK Alam Al Azhar Kutai Kartanegara

membantu guru untuk mengetaui sejauh mana perkembangan perilaku Anak Didik. Berdasarkan observasi dan wawancara diketahui TK Alam Al Azhar Kutai Kartanegara juga melakukan penilaian dengan fortofolio, dimana penilaian fortofolio merupakan penilaian yang dilakukan dengan cara mengumpulkan semua hasil karya anak didik dijadikan menjadi satu file untuk bahan laporan dan untuk mengetahui perkembangan psikomotor anak didik. Penilaian pada aspek psikomotor dapat dilakukan dengan mengetahui kemampuan anak didik, proyek, dan portofolio. Hal ini dapat dimaknai bahwa untuk mengetahui perkembangan psikomotor anak didik dapat digunakan penilaian fortofolio.

\section{E. Hasil Penelitian}

Proses pembelajaran di TK Alam Al Azhar Kutai Kartanegara terdiri dari perencanaan, pelaksanaan dan evaluasi. Perencanaan pembelajaran berbasis alam yang dilakukan di TK Alam Al Azhar Kutai Kartanegara terdiri dari menetapkan tahap perkembangan anak didik, menetapkan indikator, menyusun konsep materi pembelajaran, menentukan tema, menyusun rencana kegiatan pembelajaran berbasis alam, menyiapkan sumber belalar dan alat peraga pembelajaran berbasis alam. Komponen-komponen perencanaan tersebut di atas mengacu pada kurikulum yang telah diterapkan, sebagaimana yang dikemukakan Suharningsih usaha penyusunan rencana pembelajaran dilakukan dengan cara memahami kurikulum, mengumpulkaan informasi dan referensi, mengidentifikasi sumber belajar, dan mempersiapkan langkah-langkah kegiatan yang dilakukan untuk mencapai tujuan yang telah ditentukan.

Tahap awal dalam perencanan pembelajaran berbasis alam dengan menetapkan tahap perkembangan anak didik. Dimana guru harus memahami karakteristik anak didiknya karena anak usia dini mempunyai karakteristik yang berbeda dengan orang dewasa. Karakteritik tersebut meliputi berbagai hal mulai dari psikis, fisik, sosial, moral serta kemampuan lainnya. Masa anak usia PAUD merupakan masa yang paling penting sepanjang kehidupannya seperti yang 
Sunanik: Pembelajaran Berbasis Alam untuk Anak Usia Dini di TK Alam Al Azhar Kutai Kartanegara

dikemukan Mulyasa Usia 0-6 tahun, merupakan masa peka bagi anak sehingga para ahli menyebutnya The Golden age. Guru harus mampu mengetahui semua perkembangan anak didik dimana hal tersebut merupakan tahapan awal dari sebuah perencanaan pembelajaran. Pendidikan anak usia dini merupakan usia persiapan anak untuk menerima pendidikan selanjutnya di sekolah dasar. Sehingga dibutuhkan suatu pembelajaran yang mampu untuk merangsang perkembangan kompetensi anak usia dini.

Tahap kedua dalam perencanaan pembelajaran berbasis alam di TK Alam Al Azhar Kutai Kartanegara yaitu dengan menetapkan indikator pembelajaran. Indikator pembelajaran dapat dijabarkan dengan membuat Rencana Program Pembelajaran Mingguan (RPPM) dan Rencana Program Pembelajaran Harian (RPPH). Tujuan dari penyusunan RPPM dan RPPH yaitu untuk memudahkan guru dalam mempersiapan bahan dan materi pembelajaran. Dalam menyusun RPPM dan RPPH guru dituntut menguasai strategi pembelajaran dengan cara menguasai materi dengan baik sehingga dapat membuat persiapan pembelajaran. Hal tersebut sesuai dengan penelitian Suryana yang menunjukkan bahwa pengetahuan guru tentang strategi pembelajaran berpengaruh terhadap hasil belajar. Hal tersebut dapat dimaknai bahwa penyusunan RPPM dan RPPH oleh guru mutlak dilakukan guru, selain berfungsi untuk perencanaan juga berfungsi untuk memperdalam dan sarana untuk memahami materi pelajaran yang akan diberikan kepada anak didik.

Tahap ketiga dalam perencanaan adalah dengan menyusun konsep materi pelajaran berbasis alam. Guru-guru TK Alam Al Azhar Kutai Kartanegara menyusun konsep materi pembelajaran berbasis alam secara bersama dalam musyawarah. Menyusun konsep materi pembelajaran dalam perencanaan pembelajaran merupakan sesuatu yang harus dilkukan oleh guru. Karena di dalam materi itulah akan disampaikan suatu pembelajaran yang bermakna dan amanat atau inti dari suatu pembelajaran . Hal tersebut sesuai dengan penelitian yang dilakukan oleh Saifudin yang menyimpulkan bahwa kualitas pembelajaran yang sesuai dengan standar kompetensi lulusan antara 
Sunanik: Pembelajaran Berbasis Alam untuk Anak Usia Dini di TK Alam Al Azhar Kutai Kartanegara

lain dengan perencanaan materi pembelajaran dengan menyusun rencana pelaksanaan pembelajaran yang mengacu pada kompetensi standar lulusan.

Tahap yang keempat dari perencanaan adalah guru menetapkan tema pembelajaran yang berbasis alam. Tema merupakan pokok pembelajaran yang akan disampai guru didalam proses pembelajaran. Setiap tema dibahas dalam satu minggu atau dua minggu tergantung dari keluasan cakupan dan kedalaman tema tersebut. Hal tersebut sesuai dengan yang dikemukakan Badan Peneliti dan Pengembangan Pendidikan Kemendikbud bahwa pembelajaran tema adalah salah satu pembelajaran yang didasarkan atas ide-ide pokok tentang anak dan lingkungannya. Hal tersebut mendukung wawancara dan observasi peneliti dilapangan bahwa tema yang ditetapkan di TK Alam Al Azhar Kutai Kartanegara sesuai dengan lingkungan yang dikenal anak dan di sekitarnya. Paparan tersebut dapat dimaknai bahwa penetapan tema sesuai dengan kebutuhan anak didik dan lingkungannya. Tahap selanjutnya dalam perencana pembelajaran berbasis alam di TK Alam Al Azhar Kutai Kartanegara adalah menyiapkan bahan dan alat peraga pembelajaran. Alat dan bahan pembelajaran berbasis alam dapat di luar kelas (outdoor) misalnya perosotan , jungkat jungkit, papan titian, pasir, tumbuhan sekitar kolam ikan, sedangkan didalam kelas misalnya krayon, unit balok lego, bak air botol tempat air, puzzle, gunting, krayon. Hal tersebut sesuai dengan penelitian yang dilakukan oleh Sutama bahwa kondisi fisik ruang kelas memiliki pengaruh pada kemungkinan gangguan dalam pembelajaran. Hal tersebut dapat dimaknai bahwa penataan ruang kelas yang baik dan terencana dengan berbagai macam media,alat dan bahan pembelajaran dapat meningkatkan pemahaman anak didik terhadap materi yang diajarkan oleh guru.

Pelaksanaan pembelajaran berbasis alam di TK Alam Al Azhar Kutai Kartanegara dilaksanakan didalam kelas (indoorlearning) dan diluar kelas (out doorlearning). Pembelajaran di luar kelas di buat senyata mungkin dengan melihat, mengamati dan berinteraksi dengan objek secara langsung, sehingga pembelajaran tersebut menjadi bermakna dan dapat memberi pengalaman nyata.

Jurnal Ilmiah AL-MADRASAH, Vol. 3, No. 1, Juli-Desember 2018 
Sunanik: Pembelajaran Berbasis Alam untuk Anak Usia Dini di TK Alam Al Azhar Kutai Kartanegara

Hal tersebut sesuai dengan penelitian yang dilakukan oleh Robert A. Montgomery and Kelly F Millenbah menunjukan bahwa Anak Didik yang belajar diluarkelas secara signifikan lebih baik dibandingkan dengan anak didik yang belajar di dalam kelas. Pembelajaran berbasis alam yang dilakukan TK Alam Al Azhar Kutai Kartanegara juga mendukung penelitian yang dilakukan oleh Theodore S May menyimpulkan bahwa kualitas pembelajaran di luar kelas memberikan pengalaman yang sangat berharga bagi anak didik. Hal tersebut dapat dimaknai bahwa pembelajaran berbasis alam yang dilaksanakan diluar kelas dapat meningkatkan pemahaman anak didik terhadap materi yang disampaikan guru

Berdasarkan observasi dilapangan yang dilakukan oleh peneliti menunjukkan bahwa anak didik yang melakukan pembelajaran di luar kelas sangat antusias dan sangat senang sekali. Pemanfaatan lingkungan sekolah yang rindang dengan berbagai tanaman sebagai tempat belajar juga merupakan suatu metode yang sangat efektif. Pembelajaran berbasis alam dengan memanfaatkan benda-benda nyata di lingkungan sekolah mendukung penelitian yang dilakukan oleh Liu, Lin menyimpulkan bahwa anak didik lebih memahami peran sayur kangkung dalam sistem ekologi melalui pengamatan langsung. Hal tersebut dapat dimaknai bahwa anak didik dapat dengan mudah memahami materi dengan mengamati bendanya secara langsung nyata. Hal tersebut juga di dukung oleh penelitian Bay menyimpulkan bahwa pembelajaran di luar kelas dengan praktik langsung dan melakukan eksperimen langsung dengan suasana alam yang menyenangkan akan meningkatkan kemampuan berfikir positif dan kreatif anak didik. Hal ini dapat dimaknai bahwa pembelajaran di alam terbuka akan menjadikan anak didik lebih kreatif.

Pembelajaran berbasis alam juga dilaksanakan di dalam kelas, dengan cara semua bahan dan alat yang berhubungan dengan alam di pindah ke dalam kelas misalnya tumbuhan kecil, sayuran, buah-buahan, daun, batu, pasir, tanah, ranting, hewan dan sebagainya yang memungkinkan untuk di bawa masuk kedalam kelas. Kemudian anak didik dibuat berkelompok untuk mengamati 
Sunanik: Pembelajaran Berbasis Alam untuk Anak Usia Dini di TK Alam Al Azhar Kutai Kartanegara

melihat dan berinteraksi dengan benda secara langsung. Pembelajaran yang dilakukan TK Alam Al Azhar Kutai Kartanegara dengan pembelajaran secara berkelompok di dalam kelas mendukung penelitian yang dilakukan oleh Liu, Lin menyimpulkan bahwa dengan satu materi tentang sayur kangkung anak didik dapat melakukan pengamatan melalui dua kelompok, kelompok satu mengamati di lingkungan ekolagi dan kelompok kedua mengamati di laboratorium. Hal itu dapat maknai bahwa dengan materi yang sama dapat dilakukan pembelajaran yang bervariasi baik di dalam ruangan ( laboratorium, kelas) maupun menggunakan lingkungan alam sebagai sumber belajar.

Dalam pembelajaran berbasis alam TK Alam Al Azhar Kutai Kartanegara melakukan penilaian pembelajaran. Menurut Percival (2013) mengatakan bahwa penilaian adalah serangkaian kegiatan yang dirancang untuk mengukur keefektifan sistem mengajar/belajar sebagai suatu keseluruhan. Penilaian yang dilakukan oleh guru meliputi tiga hal yaitu pengamatan, catatan anekdot, dan fortofolio. Hal tersebut sesuai dengan penelitian yang dilakukan oleh Sabzian mengatakan bahwa guru merupakan salahsatu pondasi penting dalam semua sistem pendidikan. Hasil penelitian tersebut membahas mengenai evaluasi untuk meningkatkan kualitas guru, guru yang berkualitas dapat melakukan penilaian dengan baik dan benar untk meningkat prestasi belajar anak didik. Hal tersebut dapat dimaknai bahwa guru yang berkualitas dapat melakukan berbagai macam penilaian dengan pengamat, catatan anekdot dan fortofolio secara menyeluruh dan tuntas. Penilaian dengan pengamatan merupakan suatu bentuk penilaian yang paling sederhana tapi dapat memberikan suatu hasil yang sangat bermakna, penilaian dengan pengamatan dilakukan untuk menilai aspek afektif atau tingkah laku hal ini mendukung penelitian. Sutama, Narimo,Samino menyimpulkan bahwa penilaian pada aspek afektif dilakukan dengan pengamatan, jurnal guru, penilaian sendiri, dan penilaian dari rekan. Hal tersebut dapat dimaknai bahwa penilaian pengamatan digunakan untuk menilai pada aspek afektif atau tingkah laku anak didik. Berdasarkan pengamatan dan wawancara menunjukkan penilaian kedua yang 
Sunanik: Pembelajaran Berbasis Alam untuk Anak Usia Dini di TK Alam Al Azhar Kutai Kartanegara

dilakukan oleh guru TK Alam Al Azhar Kutai Kartanegara adalah dengan catatan anekdot, dimana dalam catatan anekdot tersebut guru mencatat semua perkembangan anak didik selama pembelajaran berbasis alam.

Catatan anekdot ini berbentuk tabel yang isinya nomor dan jenis kegiatan. Penilaian dengan catatan anekdot yang di lakukan TK Alam Al Azhar Kutai Kartanegara mendukung penelitian Sutama, Narimo, Samino menyimpulkan bahwa penilaian pada aspek afektif dilakukan dengan pengamatan, jurnal (catatan) guru, penilaian sendiri, dan penilaian dari rekan. Maka dapat dimaknai bahwa penilaian dengan catatan anekdot dapat membantu guru untuk mengetahui sejauh mana perkembangan perilaku anak didik. Berdasarkan observasi dan wawancara diketahui TK Alam Al Azhar Kutai Kartanegara juga melakukan penilaian dengan fortofolio, dimana penilaian fortofolio merupakan penilaian yang dilakukan dengan cara mengumpulkan semua hasil karya anak didik dijadikan menjadi satu file untuk bahan laporan dan untuk mengetahui perkembangan psikomotor anak didik. Hal tersebut sesuai dengan penelitian yang dilakukan oleh Sutama, Narimo, Samino yang menyimpukan bahwa penilaian pada aspek psikomotor dapat dilakukan dengan mengetahui kemempuan anak didik, proyek, dan portofolio. Hal ini dapat dimaknai bahwa untuk mengetahui perkembangan psikomotor anak didik dapat digunakan penilaian fortofolio

\section{F. Simpulan}

Pembelajaran berbasis alam di TK Alam Al Azhar Kutai Kartanegara terdiri dari perencanaan pembelajaran meliputi menetapkan perkembangan peserta didik, menetapkan indikator pembelajaran, menyusun konsep materi, menetapkan tema pembelajaran dan menyiapkan bahan dan alat peraga. Pelaksanaan pembelajaran berbasis alam di TK Alam Al Azhar Kutai Kartanegara dilaksanakan dengan pembelajaran di dalam kelas ( indoor learning ) dan di luar kelas (out learning ) yang bertujuan untuk meningkatkan pemahaman siswa dan menjadikan pembelajaran menjadi bermakna bagi pesertadidik. Penilaian pembelajaran berbasis alam di TK Alam Al Azhar 
Sunanik: Pembelajaran Berbasis Alam untuk Anak Usia Dini di TK Alam Al Azhar Kutai Kartanegara

Kutai Kartanegara dilakukan dengan pengamatan, catatan anekdot dan portofolio. Penilaian tersebut di gunakan untuk mengukur kompetensi anak didik. Guru harus meningkatkan perencanaan pembelajaran dengan matang dan terstruktur agar pembelajaran berjalan maksimal dan efektif.

Jurnal Ilmiah AL-MADRASAH, Vol. 3, No. 1, Juli-Desember 2018 
Sunanik: Pembelajaran Berbasis Alam untuk Anak Usia Dini di TK Alam Al Azhar Kutai Kartanegara

\section{Daftar Pustaka}

Anita, Yus. Penilaian Belajar Anak Taman Kanak-Kanak, Jakarta: Departemen Pendidikan Nasional, 2005

Aqib, Zainal. Model-Model, Media, dan Strategi Pembelajaran Konstektual (Inovatif), Bandung: YramaWidya, 2013

Arikunto,Suharsimi. Metodologi Penelitian Kualitatif, Jakarta: Grafindo Persada, 1991

Cepi Riyana dan Toto Fathoni. Komponen-Komponen Pembelajaran, Jakarta: Raja Grafindo, 2011

Hadi, Sutrisno. Metodologi Research, Jakarta: UGM Press, 1993

Hamalik, Oemar. Proses Belajar Mengajar. Jakarta : Bumi Aksara, 2013

Husin, Husin. "Pendidikan Agama Islam Di Amerika Serikat (Lembaga Pendidikan Islam)." Al-Madrasah: Jurnal Ilmiah Pendidikan Madrasah Ibtidaiyah 2, no. 2 (2018).

M. Fadillah, Desain pembelajaran PAUD: Panduan untuk Pendidikan Mahasiswa, dan Pengelola Pendidikan Anak Usia Dini. Yogyakarta: Ar-Ruzz Media, 2012

Marimba, D Ahmad. Pengantar Filsafat Pendidikan Islam, Bandung: AlBayan, 1996

Michael and Mattew. B, Milles Huberman. Analisis Data Kualitatif, (terj), Jakarta: UI Press, 1984

Moeslichatoen R. Metode Pengajaran Di Taman Kanak-Kanak,(Jakarta: PT Asdi Mahasatya, 2004

Moleong, Lexy. Metode penelitian Kualitatif, Jakarta: Remaja Rosda Karya, 2004

Muhajir, Noeng. Metode Penelitian Kualitatif, Yogyakarta: Rake Sarasin, 2000

Mulyasa, Manajemen Berbasis Sekolah, Konsep, Strategi dan Implemetasi, Bandung: PT Remaja Rosdakarya, 2011

Munif, Chatib. Gurunya Manusia: Mejadikan Semua Anak Istimewa dan Semua Anak Juara, Bandung: Mizan, 2011

Nurani Sujiono, Yuliani. Konsep Dasar Pendidikan Anak Usia Dini, Jakarta: Indeks, 2009

Permasih dan Darmawa, Konsep Dasar Pembelajaran dalam Tim Pengembang MKDP Kurikulum dan Pembelajaran, Jakarta: PT Rajagrafindo Persada, 2011 
Sunanik: Pembelajaran Berbasis Alam untuk Anak Usia Dini di TK Alam Al Azhar Kutai Kartanegara

PERMENDIKBUD 137, Standar Nasional Pendidikan Anak Usia Dini. Jakarta:Permedikbud. 2014

Riduan, Metode dan Teknik Penyusunan Tesis, Bandung: Alfabeta, 2004

Rusman, Model-Model Pembelajaran, Jakarta: Raja Grafindo Persada, 2011

Saleh, S., \& Sugito, S., Implementasi metode bermain peran untuk meningkatkan kecerdasan interpersonal anak usia 5-6 tahun di TK Barunawati. Jurnal Pendidikan dan Pemberdayaan Masyarakat, 2(1), 85-93. Retrieved from http://journal.uny.ac.id/index.php/jppm/article/view/4845. 2015

Sanjaya, Wina. Strategi Pembelajaran Berorientasi Standar Proses Pendidikan, Jakarta: Prenada Media Group, 2008

Setiawan, Agus. Prinsip Pendidikan Karakter dalam Islam (Studi Komparasi Pemikiran al-Ghazali dan Burhanuddin al-Zarnuji), Dinamika Ilmu, 14 (1), 2014

Sigit, Suhardi. Pengantar Metodologi Penelitian Sosial-Bisnis- Manajemen, Bandung: Lukman Offset, 1999

Sujiono, Anas. Evaluasi Pendidikan, Jakarta: Raja Grafindo Persada, 2011

Suparwi, Peranan Cabang Muhammadiyah Terhadap Pendidikan Islam di bulu Sukoharjo, UMS, Skripsi, 2011

Syaodih Sukmadinata, Nana, Metode Penelitian Pendidikan, Bandung: Remaja Rosdakarya, 2007

Tim Pengembang BPPP Depdiknas.Model Pembelajaran Berbasis Alam Pendidikan Anak Usia Dini Formal dan Nonformal .Jakarta : Pusat Kurikulum BPPP Depdiknas. 2008

Tim Pengembang MKDP Kurikulum dan Pembelajaran, Kurikulum dan Pembelajaran, Jakarta: Raja Grafindo Persada, 2011

Uno, Hamzah, Model Pembelajaran Meciptakan Proses Belajar Mengajara yang Kreatif dan efektif, Jakarta: Bumi Aksara, 2011

Waseso, Iksan. dkk, Evaluasi Pembelajaran TK, Jakarta: Universitas Terbuka, 2011

Wortham, S. C. Early Childhood Curiculum, Columbus, Ohio: Pearson Merril Prentice Hall. 2006

Jurnal Ilmiah AL-MADRASAH, Vol. 3, No. 1, Juli-Desember 2018 
Sunanik: Pembelajaran Berbasis Alam untuk Anak Usia Dini di TK Alam Al Azhar Kutai Kartanegara

Jurnal Ilmiah AL-MADRASAH, Vol. 3, No. 1, Juli-Desember 2018 